\title{
Debussy's lasting impact on flute composition
}

\section{Kaitlin Lee \\ University of Central Oklahoma}

Introduction

\author{
Debussy's Impact
}

\section{Works that Followed}

Claude Debussy was born on August 22, 1862 in Saint-Germaine- en-Laye, France. The arts of his day were filled with Impressionism and Symbolism, France. The arts of his day were filled with Impressionism and Symbolism Debussy's include Clair de Lune, La Mer, and Prelude a I'apres- midi d'un Debussy's include Clair de Lune, La Mer, and Prelude a I'apres- midi d'un
faune. ${ }^{2}$ Looking specifically at his impact on flute composition, we will faune. 2 Looking specifically at his impact on flute composition, we will
begin to investigate Syrinx. Composed in 1913, Syrinx was not published until 1927, after Debussy's death. ${ }^{3}$

There are a few origin stories for Syrinx. One significant story details how Debussy quickly improvised the piece for Marcel Moyse at a party. Performers may want to keep this improvisatory feel. Debussy did not utilize any bar lines or phrase markings, giving freedom of interpretation. The melodic structure is based on whole tone scales. ${ }^{3}$

The name Syrinx came from a nymph that Pan, the Greek god of music, lusted after. Syrinx did not share feelings toward him, yet he pursued her. As she hid, she perished, transforming into a reed, which Pan used to make his flute. ${ }^{3}$ Syrinx then became the instrument he would use to entice nymphs, depicted in the play by Gabriel Mourey, Psyche. ${ }^{5}$ The piece Syrinx nymphs, depicted in the play by Gabriel
was used as incidental music to Psyche.

\section{Final Thoughts}

It's hard to say what unaccompanied flute repertoire would be if Syrinx had never been written. Because of improvements in tonality, color, and technique, it seems likely that someone would have started a renaissance in solo flute composition if Debussy had not. In a book by Thomas Skeffington, "The Flute in its Transition State," he details the inevitable reaction to the changes made in the flute's construction: "...but as new effects sprung forth, new music was written to embody these effects." If not Syrinx, what would that first unaccompanied piece have sounded like? Would modern unaccompanied pieces resemble the reality of today's pieces? While interesting to explore the hypothetical, Debussy did, in fac, take that first step. He saw the capabilities of the flute and wrote a piece that demonstrated its new sound. There is no doubt that the style of Syrinx made a lasting impression on the genre. Solo flute music is often descriptive of a scene or story and has loose meter and beat. Many pieces utilize whole tone scales as a part of the alluring sound, as Debussy did. Most unaccompanied flute pieces have a poetic style that seems to emanate from the 20th Century solo flute piece, Syrinx.

\section{References}

${ }^{1}$ Wye, Trevor. Trevor Wye: Flute Secrets. London: Novello \& Co Ltd., 2017. Print.

${ }^{2}$ Lockspeiser, Edward. "Claude Debussy." Britannica. Encyclopaedia

Britannica, Inc., 02 March 2017. Web. 07 March 2018.

${ }^{4}$ Ernst, Roy and Green, Douglass. Structure and Performance. Fairport, NY: Ergo Publications, 1978. Print.

${ }^{5}$ Trezise, Simon, ed. The Cambridge Companion to Debussy. Cambridge University Press, 2003. Print Per Flauto Solo With Three Recitals of Selected Works Of JS. Bach Mozart, Messiaen, Berio, Martinu, Persichetti, And Others." Diss. U of North Texas, 1992. Web. 08 March 2018.

7 "Scrivo in Vento for flute." ElliottCarter. The Amphion Foundation, Inc., "Scrivo in Vento for flute." Elliot

${ }^{8}$ Cook, Nicholas and Everist, Mark, ed. Rethinking Music. Oxford: Oxford UP, 2010. Print.
${ }^{3}$ Debussy, Claude. Syrinx. 1913. Editions Jobert, 1927. Print.

'McDermott, Dennette Derby. “Jindrich Feld's Introduzione, Toccata E Fuga

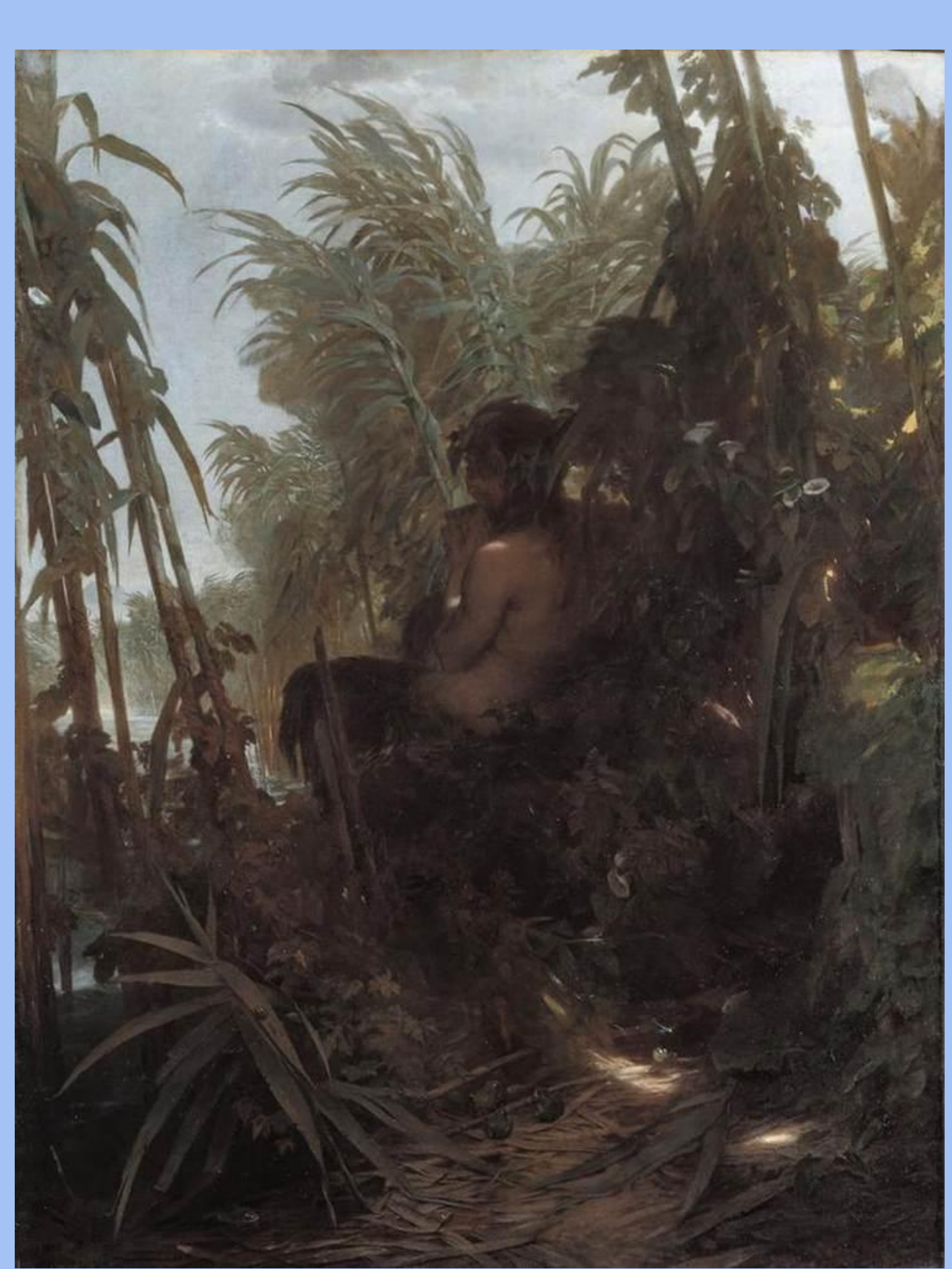

The impact that Syrinx had on 20th and 21st Century flute composition is demonstrated by the long line of solo flute works which followed. Many pieces written for solo flute demonstrate a compositional relationship to Syrinx. Jindrich Feld made use of rhythmic freedom in his Contrasts written in 1973. Both Syrinx and Contrasts give off an improvisatory impression. ${ }^{6}$ Scrivo in Vento by Elliott Carter premiered in 1991. ${ }^{7}$ Like Syrinx, it seeks to portray a scene, in this case, a poem by Petrarch, and utilizes tetrachords and the different registers of the flute to evoke the underlying story. ${ }^{8}$ The biggest influence Syrinx may have had on future solo flute composition may be using the music to tell a specific story or scene, improvisatory sound, and the use of tone colors to relay the scene more believably than was possible before the silver flute. Debussy utilized tone colors, which were relatively new, whereas following composers would begin exploring other capabilities of the flute, like flutter tonguing and multiphonics. Here are just a few of the many solo flute pieces to follow Syrinx:

Danse de la Chevre, Arthur Honegger, 1921

Oiseaux tendres, Jean Rivier, 1935

Image, Eugene Bozza, 1940

Sequenza, Luciano Berio, 1958

Fantasy Op. 89, Malcolm Arnold, 1966

Icicle, Robert Aitken, 1977

L'Oiseau Blesse, Denis Gougeon, 1987

Charanga, Michael Colquhoun, 1993

Entre Funerailles, Mark Applebaum, 2001

Single Voice, Ayala Asherov, 2010

Death of Pan, Marcos Balter, 201 